\title{
Merkel Cell Carcinoma cNX TNM Finding v8
}

National Cancer Institute

\section{Source}

National Cancer Institute. Merkel Cell Carcinoma cNX TNM Finding v8. NCI Thesaurus. Code C136849.

Merkel cell carcinoma in which the regional lymph nodes cannot be clinically assessed (e.g., previously removed for another reason, or because of body habitus). (from AJCC 8th Ed.) 